\title{
The relationship between the value of health and health behaviors in individuals over 65 years of age
}

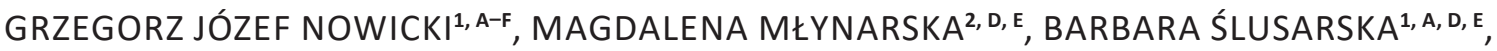 \\ EWA RUDNICKA-DROŻAK ${ }^{3, A}$, E, KATARZYNA SZCZEKALA ${ }^{4, c, E}$, AGNIESZKA BARTOSZEK ${ }^{1, c, ~ E}$
}

${ }^{1}$ Department of Family Medicine and Community Nursing, Chair of Oncology and Environmental Health, Faculty of Health Sciences, Medical University of Lublin

${ }^{2}$ Department of Emergency Medicine, Medical University of Lublin

${ }^{3}$ Department of Family Medicine, I Faculty of Medicine, Medical University of Lublin

${ }^{4}$ Department of Foreign Languages, I Faculty of Medicine, Medical University of Lublin

A - Study Design, B - Data Collection, C - Statistical Analysis, D - Data Interpretation, E - Manuscript Preparation, F - Literature Search, G - Funds Collection

Summary Background. Health is commonly regarded to be a social and individual value. It is perceived from the angle of multiple factors that determine health status.

Objectives. Evaluation of the relationship between the value of health and the health behaviors declared by primary healthcare patients over 65 years of age.

Material and methods. The study encompassed 505 patients of primary healthcare who were over 65 years of age. Those surveyed were asked to complete a questionnaire consisting of the Health Behavior Inventory (HBI) and Health Criteria List (HCL) by Z. Juczyński. Results. The findings of the study demonstrate that in the evaluation of the health behaviors of the surveyed patients above 65 years of age, the average value of the HBI was 76.49 points. Having analyzed the separate categories of health behaviors, it has been reported that preventive behaviors and health practices were rated highest. These seniors paid the greatest attention to health in terms of property and condition. Health in terms of being a goal is treated as least important. Patients with a higher general level of health behaviors less frequently perceive health in the category of an outcome $(p=0.001)$.

Conclusions. Seniors attach great significance to health understood as property or condition, which may explain their reluctant ap proach to this issue. The perception of health as an expected outcome is associated with a lower general rate of health behaviors. Key words: individuals over 65 years of age, health behaviors, value of health.

Nowicki GJ, Młynarska M, Ślusarska B, Rudnicka-Drożak E, Szczekala K, Bartoszek A. The relationship between the value of health and health behaviors in individuals over 65 years of age. Fam Med Prim Care Rev 2017; 19(1): 49-53, doi: 10.5114/fmpcr.2017.65091.

\section{Background}

Health is a fundamental value for every individual. The significance of this value comprises the following three components: the value of a healthy body, value of an ill body and value of a body endangered by disease. Health as a value indicates the possibility of gaining it $[1,2]$. The expression "being healthy" carries different meanings for individuals. It results from multiple conditions of health and depends on, among others, age, gender, social situation and the system of values that affects one's objectives in life. Generally, most individuals see health as a lack of illness, and a new meaning is applied only when a disease or health problems occur. Fundamental differences are found between the professional and lay notion of health: the former is determined by both physical function as well as social and personal resources; the latter most commonly focuses on physical and mental dimensions [3].

Health is commonly regarded as a social and individual value and is perceived from the angle of different factors that influence the condition. Therefore, it is not difficult to find various health concepts and definitions in literature; but choosing the appropriate one is dependent on the range and, mainly, the aim of research undertaken. The significance of health acquires different connotations in relation to some individuals or groups. This is applicable in the case of the elderly when the health status of an individual or the whole community of this age category is analyzed [4].
Starting pro-health activities should be connected with the individual manner of understanding health. The functional efficiency of an organism enables an individual to aim for commonly desired success as well as take control over reality. Therefore, health is quite often identified with goodness, happiness, activity, strength, beauty and well-being. The value of health is shaped by personal beliefs and the manner of living. Simultaneously, it is a point of reference for propagated behavior. It is health that makes individuals manifest their preferred system of values and lifestyle [5]. An individual's conduct towards their health also depends on many cultural factors. Among other factors, the individual hierarchy of values, knowledge, education and economic situation should be mentioned [6].

Health behavior with habits and deliberate health promoting activities can be distinguished in an individual's lifestyle focused on health. Health habits are associated with the hygiene of daily living, food preferences, physical activity and rest - they improve health, prevent diseases and contribute to early detection of disorders. Unfortunately, there are also behaviors which lead to a threat or loss of health and these are as follows: smoking, unhealthy nutrition, psychoactive substance abuse, stress, etc. The factor which determines and motivates people most to take up health behaviors is the value placed on health. The reflection of health status is subjective well-being which includes both emotional and cognitive elements [3]. The individual manner of perceiving health influences physical and mental health, life activity and realization of health behaviors that favor health. 
Prior to starting health promoting activities, it is crucial for individuals to define health and identify health with the goal, condition, property or process.

\section{Objectives}

The aim of the study was to evaluate the relationship between the value of health and the health behaviors declared in patients over 65 years of age in a primary care setting.

\section{Material and methods}

The survey was carried out from July to September 2013 and encompassed 505 patients over 65 years of age who were treated at five primary healthcare facilities in the Lublin region, where three were based in Lublin (NZOZ "ANI-MED", NZOZ "UNI-MED" and the Specialized Outpatient Clinic and of Occupational Diseases of the Countryside situated at the Institute of Rural Health) and two outside Lublin (NZOZ Poradnia Zdrowia S.C. in Turobin and NZOZ Goraj in Goraj). Patients were recruited randomly using simple randomization of every second individual over 65 who attended the outpatient clinics. The criteria to be met were being of the age of at least 65 , appropriate cognitive functions assessed through the Mini-Mental State Examination (MMSE) and the seniors' informed consent to participate in the study. The survey was conducted by means of a diagnostic questionnaire.

To evaluate health behaviors, the Health Behavior Inventory (HBI) by Z. Juczyński was applied. The tool is composed of 24 items that determine different types of health-related behaviors. It also includes a $25^{\text {th }}$ item, called "other", which enables a respondent to write their own item if different from all those presented. Those questioned choose an appropriate number for each item depending on how it refers to the individual: 1 - hardly ever, 2 - rarely, 3 - from time to time, 4 - often, 5 - almost always. The frequency of the behavior chosen by the respondent was used to determine the general intensity of behavior that favors health. Moreover, the level of intensity of four categories of health behaviors was also established, and the categories comprise "healthy eating habits", "preventive behaviors", "health practices" and "a positive mental attitude" [3]. Due to the temporal preference of different behaviors, the respondents were asked to take the most recent year into consideration.

All the results obtained were calculated to check the general rate of intensity of health behaviors. The value of the rate had been established and it ranged from 24 to 100 points; the higher the result, the higher the level of the health behaviors declared. The results were then calculated into sten scores as suggested by the author of the tool.

The Health Criteria List (HCL) by Z. Juczyński was used to find out what values of health are demonstrated by those surveyed. The tool is composed of 24 items that describe health in the physical, mental and social dimensions. The $\mathrm{HCL}$ refers to the holistic concept of health [3].

Having read and marked the criteria which are significant to the health for those questioned, five criteria were chosen to be the most essential and were eventually prioritized, starting with the most important and assigning it five points to the least important criteria, to which one point was assigned.

All the points assigned to the health criteria were the basis for interpretation of the study results and these can be related to mean values suggested by the author of the instrument. In the interpretation, it is worth considering not only the significance of the criteria but also their definitional properties which describe health in the following categories: condition, outcome, property or process [3].

If health criteria are not chosen in group studies, zero points (0) should be assigned. As a result, range prioritization of all the possible 24 health criteria is obtained to characterize a study group. The interpretation should also include consideration of frequency distribution of the ranges for particular health criteria [3].

The findings obtained were used in a statistical analysis. The Shapiro-Wilk test was utilized to check if the variables were distributed normally. The general outcome of the HBI scale, as well as its four categories, were found to differ from normal distribution; thus, the results have been shown by means of the median, minimum and maximum. The HCL results have been provided as the mean value that determines the weight of a particular item (consistent with the author's guidelines). The relationship between the respondents' level of health behaviors (HBI) and the value of health (HCL) was assessed by means of Pearson's correlation coefficient. A significance level of $p<0.05$ was assumed to indicate the presence of statistically significant differences or dependences. A database was developed and statistical analysis was conducted using Statistica 9.1 software (StatSoft, Poland).

The study procedure was approved by the Bioethics Commission of the Medical University of Lublin and was provided with the number KE-0254/242/2012 in accordance with the Helsinki Declaration.

\section{Results}

\section{Characteristics of the study group}

The study involved a total of 505 primary healthcare patients living in the Lublin region, which comprised 315 females (62.38\%) and 190 males (37.62\%). The age groups of the surveyed patients were as follows: 243 patients (48.12\%) constituted the age range of $65-75$ years, 166 patients $(32.87 \%)$ were found in the age range of 76-85 years, and finally, the group of eldest patients above 85 years of age equaled 96 patients (19.01\%). The respondents with higher and secondary education constituted 255 individuals (50.49\%) and 250 individuals (49.51\%) had vocational and elementary education or no education.

\section{Health behavior $-\mathrm{HBI}$ results}

Per standardized unit, among the 505 respondents, 43.17\% ( $n=218$ ) achieved a low value of health behaviors (within 1-4 sten), $36.43 \%$ ( $n=184$ ) obtained an average value (within 5-6 sten), and only $20.40 \%(n=103)$ obtained a high value of health behaviors (in a range between 7-10 sten). Looking at individual categories of health behavior, it was revealed that the highest value was attributed to preventive behaviors $(M=20.44 ; S D=$ 5.23 ), such as adherence to doctor's orders and obtaining information on health and disease. Health practices came second $(M=19.06$; $S D=4.09$ ), i.e. sufficient amount of sleep, physical exercises, or the manner of spending free time. The third category of health behaviors was a positive mental attitude ( $M=18.66 ; S D=4.84)$, under which it was possible to include such behaviors as avoiding intense emotions, stress, tension and depressing situations. The category assessed as lowest was healthy eating habits $(M=18.33$; $S D=5.33)$ : the type of food eaten, namely, the frequency of consumption of wholemeal bread, fruit and vegetables, salt, avoiding foods with preservatives, etc. All the in-depth data is presented in Table 1.

\begin{tabular}{|c|c|c|}
\hline & Median & Min-Max \\
\hline Healthy behaviors & 78 & $36.00-114.00$ \\
\hline Healthy eating habits & 19 & $7.00-30.00$ \\
\hline Preventive behaviors & 21 & $8.00-30.00$ \\
\hline Positive mental attitude & 19 & $6.00-30.00$ \\
\hline Health practices & 19 & $6.00-30.00$ \\
\hline
\end{tabular}




\section{Value of health $-\mathrm{HCL}$ results}

The study revealed that the seniors attach the greatest weight to health understood in the category of property or condition. To the lowest degree, they treat health as a goal. For participants above 65 years of age, health means "not to suffer from any physical symptoms" (a weighted arithmetic mean of 1.74), "to have all the body parts functioning" (a weighted arithmetic mean of 1.60) and "to feel good" (a weighted arithmetic mean of 1.45). However, less significant items are "to be able to control emotions and urges" (a weighted arithmetic mean of 0.20 ), "to have healthy sight, hair and skin" (a weighted arithmetic mean of 0.19), as well as "to be responsible" (a weighted arithmetic mean of 0.14). All the detailed data is presented in Table 2.

\begin{tabular}{|c|c|c|c|}
\hline $\begin{array}{l}\text { No. } \\
\text { of the } \\
\text { item }\end{array}$ & Items & $\begin{array}{l}\text { Weighted } \\
\text { arithmetic } \\
\text { mean } \\
\end{array}$ & $\begin{array}{l}\text { Definition } \\
\text { of health }\end{array}$ \\
\hline 12 & $\begin{array}{l}\text { Not to suffer from any physi- } \\
\text { cal symptoms }\end{array}$ & 1.74 & Property \\
\hline 20 & $\begin{array}{l}\text { To have all the parts of the } \\
\text { body functioning }\end{array}$ & 1.60 & Property \\
\hline 23 & To feel good & 1.45 & Condition \\
\hline 14 & $\begin{array}{l}\text { Not to fall ill, only flu or } \\
\text { indigestion very rarely }\end{array}$ & 0.94 & Property \\
\hline 2 & \begin{tabular}{|l|} 
To feel happy most of the \\
time
\end{tabular} & 0.92 & Condition \\
\hline 1 & To live to an old age & 0.75 & Goal \\
\hline 17 & To be able to enjoy life & 0.63 & Condition \\
\hline 8 & Not to smoke & 0.61 & Outcome \\
\hline 24 & $\begin{array}{l}\text { Hardly ever have to go to the } \\
\text { doctor's }\end{array}$ & 0.52 & Property \\
\hline 5 & To eat healthily & 0.51 & Outcome \\
\hline 11 & To be in a good mood & 0.50 & Property \\
\hline 4 & $\begin{array}{l}\text { To be able to solve one's own } \\
\text { problems }\end{array}$ & 0.49 & Process \\
\hline 3 & $\begin{array}{l}\text { To be able to get on well with } \\
\text { people }\end{array}$ & 0.43 & Process \\
\hline 6 & To get sufficient rest and sleep & 0.40 & Outcome \\
\hline 21 & $\begin{array}{l}\text { To accept oneself, to be } \\
\text { aware of one's strengths and } \\
\text { weaknesses }\end{array}$ & 0.37 & Goal \\
\hline 7 & To drink little or no alcohol & 0.35 & Outcome \\
\hline 9 & $\begin{array}{l}\text { To have a healthy body } \\
\text { weight }\end{array}$ & 0.35 & Outcome \\
\hline 16 & $\begin{array}{l}\text { To be able to adapt to } \\
\text { changes in life }\end{array}$ & 0.35 & Process \\
\hline 10 & $\begin{array}{l}\text { To take medicines only oc- } \\
\text { casionally }\end{array}$ & 0.34 & Property \\
\hline 13 & $\begin{array}{l}\text { To be able to work without } \\
\text { tension and stress }\end{array}$ & 0.32 & Process \\
\hline 22 & $\begin{array}{l}\text { To have work, diverse } \\
\text { interests }\end{array}$ & 0.21 & Property \\
\hline 19 & $\begin{array}{l}\text { To be able to control emo- } \\
\text { tions and urges }\end{array}$ & 0.20 & Process \\
\hline 15 & $\begin{array}{l}\text { To have healthy sight, hair } \\
\text { and skin }\end{array}$ & 0.19 & Property \\
\hline 18 & To be responsible & 0.14 & Goal \\
\hline
\end{tabular}

\section{Value of health and health behaviors declared}

Significant differences were found while correlating the $\mathrm{HBI}$ health behaviors with particular categories of the HCL. Patients who achieved a higher level of general health behaviors less of- ten treat health in terms of outcome $(r=0.143 ; p=0.001)$. The most statistically significant differences can be observed in the $\mathrm{HBI}$ category of health, which concerns a positive mental attitude. A statistically significant positive correlation was found between the category of health behavior of a positive mental attitude and the perception of health as a goal $(r=0.132 ; p=0.003)$ and process $(r=0.101 ; p=0.023)$. The level of understanding of health in the category of a goal and process increases along with the growth in the level of health behaviors in the category of a positive mental attitude. The assessment of the category of a positive mental attitude decreases along with the category of health as condition $(r=-0.145 ; p=0.001)$ and property $(r=$ $-0.097 ; p=0.029$ ). Seniors who declared a higher level of health behaviors in the category of preventive behaviors $(r=-0.093$; $p=0.037)$ and health practices $(r=-0.234 ; p<0.001)$ more seldom treated health as outcome (Table 3 ).

Table 3. Level of health behaviors according to the $\mathrm{HBI}$ and the number of indications of particular health categories according to the $\mathrm{HCL}$

\begin{tabular}{|l|l|l|l|l|l|l|}
\hline HCL & & $\begin{array}{l}\text { Healthy } \\
\text { behav- } \\
\text { iors }\end{array}$ & $\begin{array}{l}\text { Healthy } \\
\text { eating } \\
\text { habits }\end{array}$ & $\begin{array}{l}\text { Preven- } \\
\text { tive be- } \\
\text { haviors }\end{array}$ & $\begin{array}{l}\text { Positive } \\
\text { mental } \\
\text { attitude }\end{array}$ & $\begin{array}{l}\text { Health } \\
\text { prac- } \\
\text { tices }\end{array}$ \\
\hline Condition & $r$ & -0.038 & 0.004 & -0.037 & -0.145 & 0.064 \\
\cline { 2 - 7 } & $p$ & 0.390 & 0.927 & 0.408 & $0.001^{*}$ & 0.152 \\
\hline \multirow{2}{*}{ Goal } & $r$ & 0.060 & 0.036 & 0.063 & 0.132 & -0.049 \\
\cline { 2 - 7 } & $p$ & 0.175 & 0.416 & 0.155 & $0.01^{*}$ & 0.269 \\
\hline Process & $r$ & 0.031 & 0.019 & -0.029 & 0.101 & 0.013 \\
\cline { 2 - 7 } & $p$ & 0.489 & 0.671 & 0.517 & $0.05^{*}$ & 0.779 \\
\hline \multirow{2}{*}{ Property } & $r$ & 0.002 & -0.042 & 0.041 & -0.097 & 0.126 \\
\cline { 2 - 7 } & $p$ & 0.960 & 0.346 & 0.358 & $0.05^{*}$ & $0.01^{*}$ \\
\hline \multirow{2}{*}{ Outcome } & $r$ & -0.143 & -0.065 & -0.093 & -0.100 & -0.234 \\
\cline { 2 - 7 } & $p$ & $0.001^{*}$ & 0.144 & $0.05^{*}$ & $0.05^{*}$ & $0.001^{*}$ \\
\hline
\end{tabular}

$r$-Pearson's correlation coefficient, $p$ - statistical significance of differences, ${ }^{*}$ - statistically significant.

For further statistical analyses, the ten most important items of the $\mathrm{HCL}$ were included to assess the influence of value of health on health behaviors.

The statistical analysis revealed that the higher the general level of health behaviors, the less frequently the respondents marked the health criteria as "not to smoke" ( $r=-0.201$; $p<0.001)$, "not to suffer from any physical symptoms" ( $r=-121$; $p=0.006)$ and "to feel good" $(r=-0.102 ; p=0.021)$. However, most frequently they chose "not to fall ill, only with flu or indigestion very rarely" $(r=0.200 ; p<0.001)$ and "to be able to enjoy life" ( $r=0.113 ; p=0.011)$.

Seniors with a higher category of health behaviors rarely chose the following health criteria: "healthy eating habits", "not to smoke" ( $r=-0.154 ; p=0.001)$ and "to feel good" ( $r=-0.104$; $p=0.020$ ). More frequently they marked "not to fall ill, only with flu or indigestion very rarely" $(r=-0.161 ; p<0.001)$ and "to be able to enjoy life" ( $r=0.130 ; p=0.004)$, which turned out to be statistically significant.

However, along with the increase in comprehension of health as "not to fall ill, only with flu or indigestion very rarely" $(r=0.175 ; p<0.001)$, the assessment of health behaviors in the category of preventive behaviors increases; adversely, it falls along with the comprehension of health as "not to smoke" $(r=-0.150 ; p=0.001)$ and "to feel good" $(r=-0.115 ; p=0.01)$.

The respondents who opted for a positive mental attitude as the most important category more frequently chose the following health criteria: "to live to an old age" $(r=0.146 ; p=$ 0.001 ) and "not to fall ill, only with flu or indigestion very rarely" $(r=-0.108 ; p=0.015)$, which was statistically significant. The criteria which were marked the most seldom were as follows: "to feel happy most of the time" $(r=-0.108 ; p=0.015)$, "not to 
Table 4. Relationship between health behaviors according to the HBI and 10 most frequently chosen items of health according to the

\begin{tabular}{|c|c|c|c|c|c|c|}
\hline $\mathrm{HCL}$ & & $\begin{array}{l}\text { Level of health } \\
\text { behavior }\end{array}$ & $\begin{array}{l}\text { Healthy eating } \\
\text { habits }\end{array}$ & \begin{tabular}{|l} 
Preventive \\
behavior
\end{tabular} & $\begin{array}{l}\text { Positive mental } \\
\text { attitude }\end{array}$ & $\begin{array}{l}\text { Healthy prac- } \\
\text { tices }\end{array}$ \\
\hline \multirow[t]{2}{*}{ 1. To live to an old age } & $r$ & 0.044 & 0.028 & 0.020 & 0.146 & -0.063 \\
\hline & $p$ & 0.325 & 0.533 & 0.655 & $0.001 *$ & 0.156 \\
\hline \multirow[t]{2}{*}{ 2. To feel happy most of the time } & $r$ & -0.039 & 0.021 & -0.024 & -0.108 & -0.019 \\
\hline & $p$ & 0.386 & 0.634 & 0.588 & $0.015^{*}$ & 0.664 \\
\hline \multirow[t]{2}{*}{ 5. To eat healthily } & $r$ & 0.014 & 0.061 & 0.059 & 0.010 & -0.112 \\
\hline & $p$ & 0.750 & 0.171 & 0.187 & 0.818 & $0.012^{*}$ \\
\hline \multirow[t]{2}{*}{ 8. Not to smoke } & $r$ & -0.201 & -0.154 & -0.150 & -0.105 & -0.266 \\
\hline & $p$ & $<0.001^{*}$ & $0.001 *$ & 0.001* & 0.019* & $<0.001^{*}$ \\
\hline \multirow{2}{*}{$\begin{array}{l}\text { 12. Not to suffer from any physical } \\
\text { symptoms }\end{array}$} & $r$ & -0.121 & -0.067 & -0.059 & -0.202 & -0.071 \\
\hline & $p$ & $0.006 *$ & 0.135 & 0.184 & $<0.001$ & 0.111 \\
\hline \multirow{2}{*}{$\begin{array}{l}\text { 14. No to fall ill, only with flu or } \\
\text { indigestion very rarely }\end{array}$} & $r$ & 0.200 & 0.161 & 0.175 & 0.131 & 0.189 \\
\hline & $p$ & $<0.001^{*}$ & $<0.001^{*}$ & $<0.001^{*}$ & 0.003* & $<0.001^{*}$ \\
\hline \multirow[t]{2}{*}{ 17. To be able to enjoy life } & $r$ & 0.113 & 0.130 & 0.080 & 0.064 & 0.092 \\
\hline & $p$ & $0.011^{*}$ & $0.004^{*}$ & 0.072 & 0.151 & $0.039 *$ \\
\hline \multirow{2}{*}{$\begin{array}{l}\text { 20. To have all the parts of the } \\
\text { body functioning }\end{array}$} & $r$ & 0.024 & -0.009 & 0.027 & -0.046 & 0.125 \\
\hline & $p$ & 0.596 & 0.833 & 0.545 & 0.300 & $0.005^{*}$ \\
\hline \multirow[t]{2}{*}{ 23. To feel good } & $r$ & -0.102 & -0.104 & -0.115 & -0.098 & -0.001 \\
\hline & $p$ & $0.021^{*}$ & $0.020^{*}$ & $0.010^{*}$ & $0.027^{*}$ & 0.986 \\
\hline \multirow{2}{*}{$\begin{array}{l}\text { 24. Hardly ever to have to go to } \\
\text { the doctor's }\end{array}$} & $r$ & 0.052 & -0.006 & 0.074 & 0.059 & 0.048 \\
\hline & $p$ & 0.243 & 0.892 & 0.099 & 0.189 & 0.286 \\
\hline
\end{tabular}

$r$ - Pearson's correlation coefficient, $p$ - statistical significance of differences, * - statistically significant.

smoke" ( $r=-0.105 ; p=0.019)$, "not to suffer from any physical symptoms" $(r=-0.202 ; p<0.001)$ and "to feel good" $(r=-0.098$; $p=0.027)$.

Seniors who presented the highest health behaviors in the category of health practices most frequently marked the following health criteria: "not to fall ill, only with flu or indigestion" $(r=$ $0.189 ; p<0.001)$, "to be able to enjoy life" $(r=0.092 ; p=0.039)$ and "to have all the parts of the body functioning" $(r=0.125$; $p=0.005)$. The perception of health in the two criteria "to eat healthily" ( $r=-0.112 ; p=0.012)$ and "not to smoke" $(r=-0.266$; $p<0.001$ ) was chosen least often. Detailed data is presented in Table 4.

\section{Discussion}

Ageing is a physiological process that, along with concomitant pathological changes, affect the deterioration of health. Contemporary medicine has contributed to the lengthening of one's life span both in men and women; although, new problems concerning quality of life have arisen [7]. This results in the pursuit of solutions that could facilitate enjoying a good life and carrying out the activities of daily life as long as possible. Awareness of the influences in various spheres of health, as well as the ability of its practical application, is of great importance. In the opinion of Juczyński [3], a positive mental attitude, preventive behaviors, healthy eating habits and health practices are a necessity. The determination of intensity of health behaviors and the value of health for an individual helps in choosing the appropriate direction of personalized education and health promotion. In the case of multiple disorders in individuals over 65 years of age, strategies of educational actions based on a diagnosis of individual health behaviors and values of health are of great significance because they serve as an aid for developing crucial psychological and social skills. The aforementioned thesis has been proven in the research of Kurpas et al. [8], who assessed health behaviors in chronically ill patients (diabetes mellitus, cardiovascular diseases, nervous system diseases). The authors reported that diabetic patients achieved the highest scores for the assessment of health behaviors according to the $\mathrm{HBI}$ in comparison with other groups, which can be connected with the provision of broad health education for these particular patients. The authors' own results indicate that $79.6 \%$ of the surveyed seniors presented low and average health behaviors on the $\mathrm{HBI}$ scale. Similar findings were obtained in a group of 394 elderly individuals in the survey carried out by Kozieł et al. [9]. Smoleń et al. [10] reported that almost half of a group of 88 seniors $(43.2 \%)$ in the district of Sanok reached a high level of health behaviors measured with the $\mathrm{HBI}$. Research into inpatients of a geriatric ward $(n=110)$, performed by Muszalik et al. [11], also revealed that elderly individuals obtained a higher level of health behaviors than the average that was standardized for the Polish population, described by the author of the tool [3]; however, the difference was not statistically significant. Similar results obtained by means of the HBI on a group of students of the University of the Third Age were presented by Dębska et al. [12].

The manner of defining the notion of health has many determinants and evolves throughout life. Health is an extraordinary value for every individual irrespective of age. Research conducted by means of the $\mathrm{HCL}$ revealed that students interpret health as condition and property [13], individuals of reproductive age see health as condition, outcome and property [14], while individuals over 65 years of age, who participated in the authors' survey, perceive health as property and condition. It is worth noticing that health as a goal for all the aforementioned groups was rated lower; thus, individuals' awareness of health as a goal throughout their lives should be raised through health promoting activities.

Pro-health behaviors are of great significance, as they allow for the maintenance of autonomy and independence in the activities of daily life at an older age, as well as an improvement in the quality of life. To cope with difficulties that occur at an older age, individuals should develop themselves throughout their lives and have the awareness of the fact that every single individual works towards a better quality of life in their old age 
[15]. The authors' own study shows that those seniors who see health as condition, property and outcome also achieved a lower level of health behaviors for the category of a positive mental attitude, whereas those surveyed who understand health as a goal and process obtained a higher level of health behaviors for the category of positive mental attitude. Moreover, the study demonstrates that comprehension of health as property negatively correlates with the general evaluation of health behaviors, while an understanding of health as outcome negatively correlates with the general evaluation of health behaviors and with all the other categories apart from healthy eating habits. Biernacka et al. [16] reported that a group of seniors attached the greatest significance to health understood as property, process and goal, while health as condition and outcome was rated lower. According to those surveyed, to be healthy means "not to suffer from any physical symptoms", "to have all the parts of the body functioning", "to be able to get on well with people", "to accept oneself and know one's own strengths and weaknesses", "to feel good" and "to live to an old age".

Source of funding: This work was funded by the authors' resources. Conflict of interest: The authors declare no conflict of interests.

\section{Conclusions}

Individuals over 65 years of age, who are patients of a primary care facility, exhibit moderately intense health behaviors. Seniors attach great weight to health identified with the category of property or condition, which may explain their reluctant approach to this issue. The perception of health as an expected outcome is associated with a lower general rate of health behaviors.

Both significance of health and judgment of health play a crucial role in the assessment of seniors' pro-health awareness. The determination of deficits of seniors' health behaviors could facilitate selecting patients who need health education. Such individuals should participate in certain health promoting programs held by primary care providers, particularly family doctors. It is worth considering the implementation of educational programs regarding health behaviors in seniors in primary care practice.

\section{References}

1. Aue W. Współczesne tendencje w definiowaniu zdrowia. Art Dent 2010; 8(3): 234-236.

2. Żiżka-Salamon D, Szyndera M, Wiązek U. Zdrowie - wartość uznawana czy realizowana przez studentów. Annales UMCS Sect D 2005; 60(Suppl. 16): 477-480.

3. Juczyński Z. Narzędzia pomiaru w promocji i psychologii zdrowia. Warszawa: Pracownia Testów Psychologicznych Polskiego Towarzystwa Psychologicznego; 2012.

4. Coupland N, Coupland J. Discourses of ageism and anti-ageis. J Aging Stud 1993; 7: 132-144.

5. Domaradzki J. O skrytości zdrowia. O problemach z konceptualizacją pojęcia zdrowie. Hygeia Public Health 2013; 48(4): 408-419.

6. Majchrowska A. Społeczne definiowanie i wartościowanie zdrowia - wskazaniem dla pracy pielęgniarskiej. Probl Pielęg 2001; 1(2): $15-19$.

7. Kaczmarczyk M, Trafiałek E. Aktywizacja osób w starszym wieku jako szansa na pomyślne starzenie. Gerontol Pol 2007; 15(4): 116-118.

8. Kurpas D, Kusz J, Jedynak T, et al. Ocena częstości podejmowania zachowań zdrowotnych w grupie pacjentów chorych przewlekle. Fam Med Prim Care Rev 2012; 14(2): 183-185.

9. Kozieł D, Kaczmarczyk M, Naszydłowska E, et al. Wpływ kształcenia w Uniwersytecie Trzeciego Wieku na zachowania zdrowotne ludzi starszych. Stud Med 2008; 12: 23-28.

10. Smoleń E, Gazdowicz L, Żyłka-Reut A. Zachowania zdrowotne osób starszych. Pielęg XXI w 2011; 3(36): 5-9.

11. Muszalik M, Zielińska-Więczkowska H, Kędziora-Kornatowska $\mathrm{K}$, et al. Ocena wybranych zachowań sprzyjających zdrowiu wśród osób starszych w oparciu o Inwentarz Zachowań Zdrowotnych Juczyńskiego w aspekcie czynników socjo-demograficznych. Probl Hig Epidemiol 2013; 94(3): 509-513.

12. Dębska G, Korbel-Pawlas M, Zięba M, et al. Jakość życia a zachowania zdrowotne w grupie uczestników Uniwersytetu Trzeciego Wieku - badania wstępne. Zdr Pub/ 2012; 122(1): 48-54.

13. Piasecka H, Ślusarska B, Nowicki G. Zdrowie jako wartość wśród młodzieży studenckiej w uwarunkowaniach społeczno-demograficznych i ocena żywienia badanej grupy. Pielęg Pol 2015; 56(2): 127-134.

14. Nowicki G, Ślusarska B. Determinanty społeczno-demograficzne wartościowania zdrowia wśród pracujących osób dorosłych. Hygeia Public Health 2011; 46(2): 280-285.

15. Zielińska-Więczkowska H, Kędziora-Kornatowska K, Kornatowski T. Starość jako wyzwanie. Gerontol Pol 2008; 16(3): 131-136.

16. Biernacka B, Pieniążek $M$, Pyć $M$, et al. Ocena zachowań zdrowotnych i analiza zdrowia jako wartości w ocenie studentów Uniwersytetu Trzeciego Wieku Marii Curie Skłodowskiej w Lublinie. Zdrowie i Dobrostan 2015; 2: 27-38.

Tables: 4

Figures: 0

References: 16

Received: 19.10.2016

Revised: 21.11.2016

Accepted: 29.12.2016

Address for correspondence:

Grzegorz Józef Nowicki, PhD

Zakład Medycyny Rodzinnej i Pielęgniarstwa Środowiskowego

Katedra Onkologii i Środowiskowej Opieki Zdrowotnej

Wydział Nauk o Zdrowiu UM

ul. Staszica 6

20-081 Lublin

Polska

Tel.: +48 814 486-810

E-mail: grzesiek_nowicki@interia.pl 